\title{
Uji efektivitas ekstrak daun sendok (Plantago major L.) terhadap waktu perdarahan pada tikus Wistar jantan (Rattus norvegicus)
}

\author{
${ }^{1}$ Abedneju R. Kainde \\ ${ }^{2}$ Damajanty H. C. Pangemanan, \\ ${ }^{3}$ Bernart S. P. Hutagalung
}

${ }^{1}$ Kandidat Skripsi Program Studi Pendidikan Dokter Gigi Fakultas Kedokteran

${ }^{2}$ Bagian Fisiologi Fakultas Kedokteran

${ }^{3}$ Program Studi Pendidikan Dokter Gigi Fakultas Kedokteran

Universitas Sam Ratulangi Manado

Email: juniorkainde95@gmail.com

\begin{abstract}
Herbal plant is often used to treat any kind of disease. There are many kinds of plants in Minahasa used as traditional medicine, inter alia daun sendok (Plantago major L.). Daun sendok is often used to treat bleeding. This study was aimed to obtain the effectiveness of daun sendok extract on bleeding time in male Wistar rats. This was a true experimental study with a posttest only group design. This study was conducted at the Laboratory of Pharmacology Faculty of Medicine University of Sam Ratulangi. Total samples were 14 rats divided into 2 groups: control group and treatment group. Wounds of $2 \mathrm{~mm}$ depth were perfomed on the rat tails of the treatment group followed by application of daun sendok extract. The results showed that the average bleeding time of the control group was 51.87 seconds meanwhile of the treatment group was 29.67 seconds. The unpaired t-test between the two groups showed a $\mathrm{p}$ value of 0.000 . Conclusion: Daun sendok (Plantago major L.) extract could reduce the bleeding time in male Wistar rats.
\end{abstract}

Keywords: bleeding time, daun sendok, Wistar rat

\begin{abstract}
Abstrak: Tanaman obat seringkali digunakan untuk mengobati berbagai macam jenis penyakit. Di wilayah Minahasa terdapat banyak jenis tanaman yang digunakan sebagai obat tradisional, salah satunya ialah daun sendok (Plantago major L.) yang seringkali digunakan untuk mengobati perdarahan. Penelitian ini berrtujuan untuk mengetahui efektivitas ekstrak daun sendok terhadap waktu perdarahan tikus Wistar jantan. Jenis penelitian ialah true experimental dengan post test only control group design yang dilakukan di Laboratorium Farmakologi Fakultas Kedokteran Unsrat dengan total sampel berjumlah 14 ekor tikus Wistar yang dibagi menjadi 2 kelompok yaitu: kelompok kontrol dan kelompok perlakuan menggunakan ekstrak daun sendok. Pada kelompok uji diaplikasikan ekstrak daun sendok setelah dilakukan perlukaan di bagian ekor tikus sedalam $2 \mathrm{~mm}$. Hasil penelitian memperlihatkan rerata waktu perdarahan pada kelompok kontrol ialah 51,87 detik sedangkan pada kelompok perlakuan 29,67 detik. hasil uji t tidak berpasangan antara kedua kelompok mendapatkan nilai $\mathrm{p}=0,000$. Simpulan: Ekstrak daun sendok (Plantago major L.) efektif dalam memperpendek waktu perdarahan pada tikus Wistar.
\end{abstract}

Kata kunci: waktu perdarahan, daun sendok, tikus Wistar

Sulawesi Utara merupakan wilayah di Indonesia dengan potensi hayati yang sangat luas khususnya di bidang pengobatan. Pengobatan tradisional di daerah Minahasa masih sangat banyak khususnya penggunaan tanaman obat. Masyarakat sering menggunakan tanaman obat sebagai alternatif pengganti obat dari 
dokter karena tanaman obat relatif mudah ditemukan di sekitar tempat tinggal penduduk. Salah satu tanaman yang sering dijumpai dan digunakan dalam pengobatan tradisional ialah daun sendok (Plantago major L.). ${ }^{1}$

Daun sendok merupakan jenis tanaman herbal karena memiliki kandungan kimia diantaranya ialah flavonoid dan polifenol. Polifenol tergolong dalam antioksidan yang baik untuk kesehatan tubuh karena dapat mengurangi risiko penyakit jantung dan pembuluh darah serta kanker. Daun sendok seringkali digunakan untuk mengobati radang, melancarkan air kemih, menghentikan batuk, dan berbagai penyakit lainnya. Daun sendok juga merupakan jenis tanaman yang termasuk dalam golongan tanaman astringent yaitu golongan tanaman yang efektif dalam membantu penghentian perdarahan. ${ }^{2}$ Tanaman yang dipakai secara eksternal untuk menghentikan perdarahan disebut jenis tanaman styptic, antara lain daun sendok. ${ }^{3}$ Tanaman daun sendok juga mengandung vitamin $\mathrm{C}$, asam sitrat, dan tanin, ${ }^{2}$ yang merupakan senyawa polifenol yang bereaksi dengan menggumpalkan protein sehingga membantu proses hemostasis. $^{4}$

Hemostasis adalah proses penghentian perdarahan yang merupakan mekanisme lokal tubuh untuk mempertahankan kelangsungan hidup. Hemostasis dibagi menjadi 3 tahap yaitu konstriksi pembuluh darah, pembentukan penyumbatan trombosit, dan koagulasi darah. Proses hemostasis merupakan tahap awal penyembuhan luka. ${ }^{5}$

Dalam praktek kedokteran gigi khususnya di bidang bedah mulut seringkali dijumpai pasien dengan luka disertai perdarahan setelah selesai melakukan perawatan kedokteran gigi. Luka dan perdarahan di bagian mulut merupakan hal yang wajar dalam perawatan kedokteran gigi. Perdarahan di mulut biasanya langsung ditangani oleh dokter dengan cara memberikan kapas untuk menghentikan sementara proses perdarahan. Selama proses hemostasis pasien diinstruksikan untuk tidak mencabut kapas agar tidak menyebabkan terjadi perdarahan kembali. ${ }^{6}$
Tanaman daun sendok sering ditemukan di wilayah Sulawesi Utara khususnya Minahasa namun pemanfaatannya masih kurang khususnya di bidang pengobatan. Berdasarkan survei dan wawancara awal yang dilakukan peneliti pada masyarakat didapatkan bahwa daun sendok seringkali digunakan sebagai obat anti perdarahan dalam menangani luka. Oleh karena itu peneliti tertarik untuk melakukan penelitian tentang manfaat daun sendok dalam terhadap waktu perdarahan.

\section{BAHAN DAN METODE PENELITIAN}

Jenis penelitian ini ialah eksperimental laboratorik dengan post test only control group design. Penelitian ini dilaksanakan di Laboratorium Kimia Fakultas MIPA dan Laboratorium Farmakologi Fakultas Kedokteran Unsrat. Sampel penelitian ialah tikus Wistar jantan (Rattus norvegicus) berjumlah 14 ekor yang dibagi menjadi 5 ekor di setiap kelompok. Kriteria tikus yang dipakai yaitu aktif, usia 2-3 bulan, berat 200-250 g, dan tidak pernah digunakan untuk penelitian sebelumnya. Pada tikus dilakukan uji darah lengkap untuk mengetahui keadaan tikus sebelum dilakukan penelitian.

Daun sendok sebanyak $1 \mathrm{~kg}$ yang telah dikumpulkan dicuci dengan menggunakan air mengalir dan dikeringkan dengan tidak menggunakan matahari. Pembuatan ekstrak dengan cara maserasi menggunakan etanol 96\% untuk mengeluarkan zat aktif dari daun sendok tersebut kemudian dicampurkan sedikit cairan akuades agar ekstrak yang didapat tidak menjadi terlalu kental.

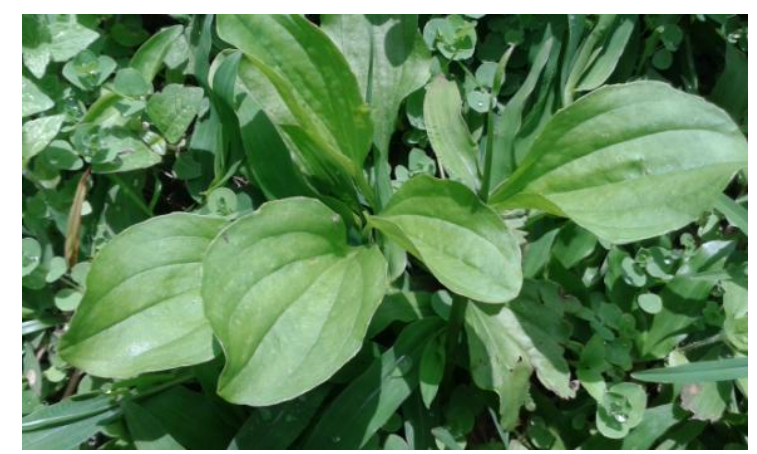

Gambar 1. Tanaman daun sendok 
Semua tikus percobaan dibuat perlukaan dalam bentuk tusukan pada ekor tikus sedalam $2 \mathrm{~mm}$ menggunakan lancet kemudian dibersihkan dengan menggunakan blotting paper. Anestesi lokal tidak digunakan agar tidak memengaruhi hasil penelitian. ${ }^{7,8}$ Aplikasi ekstrak daun sendok sebanyak 0,126 mg/g BB pada luka di ekor tikus kelompok perlakuan secara topikal menggunakan suntik $1 \mathrm{cc}$.

Perhitungan waktu perdarahan dimulai saat darah pertama kali keluar sampai darah berhenti keluar, yaitu ketika sudah tidak ada noda darah pada blotting paper. Waktu perdarahan dihitung dengan menggunakan chronometer. Darah yang dikeluar dihapus setiap 10 detik menggunakan blotting paper tanpa menekan bagian luka karena dapat memengaruhi pembentukan bekuan darah. Setelah tidak ada lagi darah yang keluar pada blotting paper, chronometer dihentikan dan dihitung jumlah waktu. Setelah selesai penelitian, tikus dieutanasia menggunakan eter $5 \%$.

Pengolahan dan analisis data dengan menggunakan SPSS dan uji normalitas Shapiro Wilk ( $\mathrm{p}>0,05)$, dilanjutkan dengan uji t tidak berpasangan $(\mathrm{p}<0,05)$. Data yang sudah diolah dan dianalisis disajikan dalam bentuk tabel.

\section{HASIL PENELITIAN}

Penelitian ini dilakukan di Laboratorium Kimia FMIPA dan Laboratorium Farmakologi Fakultas Kedokteran Unsrat pada bulan Februari-Agustus 2016. Sampel sebanyak 14 ekor tikus wistar (Rattus Norvegicus) dibagi menjadi 2 kelompok yaitu kelompok kontrol dan kelompok perlakuan. Setiap kelompok terdiri dari 5 ekor tikus. Kelompok perlakuan diberikan ekstrak daun sendok (Plantago major $L$ ) yang diperoleh melalui proses maserasi. Pada tikus dilakukan uji tes darah lengkap untuk mengetahui keadaan darah sebelum digunakan sebagai sampel.

Hasil tes darah lengkap dari sampel penelitian menunjukkan nilai WBC (White Blood Count) 13,6-15.103/mm3, RBC (Red Blood Count) 7,91-8,20.10\% $/ \mathrm{mm}^{3}$, HGB (Hemoglobin) 16,2-17,3 g/dl, PLT (Platelet
Count) $719-782.10^{3} / \mathrm{mm}^{3}, \mathrm{MCV}$ (Mean Corpuscular Volume) 55-60 L $\mu \mathrm{m}^{3}, \mathrm{MCH}$ (Mean Corpuscular Hemoglobin) 55-60 L $\mu \mathrm{m}^{3}$, RDW (Red Cell Distribution Width) 12,8-13,2\%, dan nilai MPV (Mean Platelet Volume) $7,1-8,3 \mu \mathrm{m}^{3}$. Nilai yang diperoleh termasuk kategori normal sehingga sampel dapat digunakan dalam penelitian. ${ }^{8,9}$

Tabel 3 menunjukkan bahwa setiap tikus pada kelompok kontrol memiliki berat badan yang relatif sama dengan rerata 201,2 g. Waktu perdarahan yang tertinggi 54,72 detik dan terendah 49,54 detik (rerata 51,87 detik).

Tabel 3. Hasil penghitungan berat badan dan waktu perdarahan dari kelompok kontrol

\begin{tabular}{ccc}
\hline Tikus & $\begin{array}{c}\text { Berat } \\
\text { badan }(\mathbf{g})\end{array}$ & $\begin{array}{c}\text { Waktu perdarahan } \\
\text { (detik) }\end{array}$ \\
\hline 1 & 200 & 53.21 \\
2 & 202 & 51.62 \\
3 & 202 & 49.54 \\
4 & 201 & 54.72 \\
5 & 201 & 50.26 \\
Rerata & 201,2 & 51,87 \\
\hline
\end{tabular}

Tabel 4 menunjukkan bahwa setiap tikus pada kelompok perlakuan setelah di aplikasikan ekstrak memiliki berat badan yang relatif sama dengan rerata 201,4 g. Waktu perdarahan tertinggi 32,62 detik dan waktu perdarahan terendah 27,30 detik (rerata 29,67 detik).

Tabel 4. Hasil penghitungan berat badan dan waktu perdarahan dari kelompok perlakuan setelah diaplikasikan ekstrak daun sendok

\begin{tabular}{ccc}
\hline Tikus & $\begin{array}{c}\text { Berat } \\
\text { badan }(\mathbf{g})\end{array}$ & $\begin{array}{c}\text { Waktu perdarahan } \\
\text { (Detik) }\end{array}$ \\
\hline 1 & 201 & 27,30 \\
2 & 201 & 32.62 \\
3 & 202 & 29.26 \\
4 & 200 & 31.72 \\
5 & 203 & 30.46 \\
Rerata & 201,4 & 29,67 \\
\hline
\end{tabular}

Uji normalitas Shapiro-Wilk menunjukkan bahwa waktu perdarahan tikus dari kelompok kontrol dan kelompok perlakuan memiliki nilai $\mathrm{p}>0,05$ yang menunjukkan data terdistribusi normal, dan dilanjutkan 
dengan uji t-test tidak berpasangan.

Hasil uji t-test tidak berpasangan terhadap waktu perdarahan pada kedua kelompok mendapatkan $\mathrm{p}=0,000$ yang menunjukkan terdapat perbedaan bermakna antara kelompok kontrol dan kelompok perlakuan setelah pengaplikasian ekstrak daun sendok (Tabel 5).

Tabel 5. Hasil uji t-test tidak berpasangan

\begin{tabular}{cccc}
\hline Variabel & Kelompok & n & p \\
\hline $\begin{array}{c}\text { Waktu } \\
\text { perdarahan }\end{array}$ & Perlakuan & 5 & \multirow{2}{*}{0,000} \\
\cline { 2 - 3 } & Kontrol & 5 & \\
\hline
\end{tabular}

\section{BAHASAN}

Pada tikus dilakukan pemeriksaan darah lengkap awal penelitian untuk mengetahui keadaan darah agar tidak memengaruhi hasil penelitian. Nilai WBC, $R B C, \mathrm{HGB}, \mathrm{PLT}, \mathrm{MCV}, \mathrm{MCH}, \mathrm{RDW}$, dan nilai MPV perolehan tergolong normal. ${ }^{10}$

Keadaan darah tersebut merupakan salah satu faktor yang memengaruhi waktu perdarahan tikus Bila faktor-faktor yang memengaruhi waktu perdarahan seperti jumlah eritrosit dan trombosit baik kurang atau berlebih dapat memengaruhi waktu perdarahan. $^{11}$

Pada saat penelitian terdapat 2 ekor tikus pada kelompok kontrol mengalami penurunan berat badan yang cukup besar sehingga dikeluarkan dari penelitian (drop out), dan digantikan dengan 2 ekor tikus yang sudah dipersiapkan sebelumnya.

Berdasarkan tabel rerata diketahui waktu perdarahan kelompok kontrol 51,87 detik dan waktu perdarahan kelompok perlakuan setelah diaplikasikan esktrak daun sendok lebih pendek dibandingkan waktu perdarahan kelompok kontrol dengan rerata waktu perdarahan 29,67 detik. Waktu perdarahan pada kelompok kontrol berbeda dengan penelitian yang dilakukan oleh Gracia-Manzano et al. ${ }^{8}$ pada tahun 2001 yang mendapatkan waktu perdarahan normal pada tikus Wistar jantan berkisar antara 60-110 detik. Hal ini dapat disebabkan oleh pengaruh stres dari tikus yang dapat dilihat pada kedua tikus yang dikeluarkan dari penelitian karena mengalami penurunan berat badan yang cukup signifikan.

Penelitian yang dilakukan oleh Sukma $^{12}$ menguji efektifitas daun papaya terhadap waktu perdarahan tikus Wistar dan mendapatkan rerata waktu perdarahan dari kelompok kontrol 85,75 detik, dibanding-kan dengan rerata waktu perdarahan kelompok kontrol pada penelitian ini yaitu 51,87 detik. Perbedaan sebesar 33,88 detik dapat disebabkan karena adanya perbedaan dalam prosedur persiapan pada tikus. Pada penelitian oleh Sukma tidak dilakukan pemotongan ekor tikus untuk mendapatkan sampel darah saat awal penelitian. Pemotongan ekor tikus dapat berpengaruh terhadap tingkat stres dari tikus yang mungkin memengaruhi waktu perdarahan.

Penelitian yang dilakukan oleh Wuisan et al. ${ }^{13}$ menggunakan tikus Wistar untuk mengetahui pengaruh pemberian ekstrak biji pinang terhadap waktu perdarahan pasca ekstraksi gigi pada tikus. penelitian tersebut mendapatkan bahwa rerata waktu perdarahan untuk kelompok kontrol 61,25 detik dan kelompok ekstrak 34,75 detik. Perbedaan antara penelitian Wuisan et al. ${ }^{13}$ dan penelitian ini ialah tempat pembuatan luka dimana pada penelitian yang dilakukan oleh Wuisan et al. yang menjadi tempat luka ialah bagian gigi yang dicabut, sedangkan pada penelitian ini ialah bagian ekor dari tikus Wistar.

Hasil penelitian ini menunjukkan bahwa pada kelompok perlakuan terjadi pemendekan waktu perdarahan dibandingkan pada kelompok kontrol. Analisis data menggunakan uji t-tidak berpasangan mendapatkan nilai $\mathrm{p}=0,000(\mathrm{p}<0,05)$ yang menunjukkan adanya pengaruh yang bermakna.

Hasil penelitian ini sejalan dengan penelitian oleh Nazarizadeh et al. ${ }^{14}$ di Iran yang menyatakan bahwa daun sendok mengandung banyak komponen bermanfaat dalam medis, salah satunya ialah membantu proses pemyembuhan luka khususnya mempercepat waktu perdarahan.

Penelitian yang dilakukan oleh Zubair $^{15}$ di Swedia juga menjelaskan 
bahwa daun sendok (Plantago major L.) dapat digunakan sebagai antiulserogenik, anti-inflamasi, antioksidan, antiviral, dan untuk penyembuhan luka. Hasil penelitian tersebut juga menjelaskan bahwa di dalam daun sendok terkandung flavonoid dan tannin yang membantu dalam mempercepat proses hemostasis.

Penelitian yang dilakukan oleh Audini ${ }^{16}$ menguji efektifitas ekstrak bunga papaya jantan terhadap waktu perdarahan tikus Wistar dengan metode pengambilan darah dan pengukuran waktu perdarahan yang sama. Audini mendapatkan rerata waktu perdarahan dari kelompok perlakuan 40,39 detik sedangkan rerata waktu perdarahan dari kelompok perlakuan penelitian ini 29,67 detik yaitu terdapat perbedaan sebesar 10,72 detik. Perbedaan ini dapat disebabkan karena adanya perbedaan tingkat stres tikus penelitian, atau adanya perbedaan dalam kandungan tannin dan flavonoid antara bunga papaya jantan dan daun sendok.

Keterbatasan penelitian ini ialah tingginya tingkat stres pada tikus percobaan dari kedua kelompok yang dapat dilihat dari dikeluarkannya 2 tikus dari kelompok kontrol karena penurunan berat badan yang signifikan. Hal ini dapat disebabkan oleh berbagai faktor antara lain pemotongan ekor tikus untuk pengambilan sampel darah tikus pada awal penelitian.

Hasil analisis penelitian ini menunjukkan bahwa pemberian ekstrak daun sendok (Plantago Major L) terbukti efektif secara bermakna $(\mathrm{p}=0,000)$ dalam memperpendek waktu perdarahan pada tikus Wistar (Rattus Norvegicus). Penggunaan daun sendok dapat direkomendasikan sebagai salah satu alternatif dalam menghentikan perdarahan.

\section{SIMPULAN}

Ekstrak daun sendok (Plantago major L.) efektif memperpendek waktu perdarahan tikus Wistar jantan (Rattus norvegicus).

\section{SARAN}

Penelitian ini dapat digunakan sebagai langkah awal untuk pemanfaatan daun sendok sebagai salah satu obat alternatif anti perdarahan yang dapat digunakan dalam praktek kedokteran gigi, khususnya bagian bedah mulut. Diperlukan uji toksisitas dan fitokimia untuk mengetahui lebih lanjut pengaruh kandungan dalam daun sendok.

\section{DAFTAR PUSTAKA}

1. Kinho J, Arini DID, Tabba S, Kama H, Kafiar Y, Shabri S, et al. Tumbuhan Obat Tradisional di Sulawesi Utara Jilid I. Manado: Balai Penelitian Kehutanan Manad, 2011; p. 72-7.

2. Utami P. Buku Pinter Tanaman Obat 431 Jenis Tanaman Penggempur Aneka Penyakit. Jakarta: AgroMedia, p. 65.

3. Ashok PK, Upadhyaya K. Tannins are astringent. J Pharmacogn Phytochem. 2012;1(3):45-8.

4. Kobeasy MI, Abdel-Fatah OM, El-Salam ASM, Mohamed ZEM. Biochemical studies on Plantago major L. and Cyamopsis tetragonoloba L. IJBC. 2011;3(3):83-91.

5. Rahajuningsih. Hemostasis dan Trombosis (3rd ed). Jakarta: FKUI, 2007; p. 21.

6. Harum S. Evaluasi dan penatalaksanaan perawatan gigi-mulut pada pasien dengan keganasan darah (Studi pusaka). Jurnal Kedokteran Gigi UI. 1996;3(3):92.

7. Olfret E, Cross BM, McWilliam AA, editors. Guide to the care and use of experimental animals. Ottawa: CCAC, 1993; p. 82-90.

8. Gracia-Manzano A, Gonzalez-Llaven J, Lemini C, Rubio-Poo C. Standardization of Rat Blood Clotting Test with Reagents Used for Human. Proc West Pharmacol Soc. 2001144:153-5.

9. Clifford CB. Clinical Laboratory Parameters for Crl:WI (Han) Rats. Massachusetts: Charles River, 2008; p. 6.

10. Lemini C, Jaimez R, Franco Y. Gender and interspecies influence on coagulation tests of rats and mice. Thromb Res. 2007;120(3):415-9.

11. Hoffman M. Mechanism of Hemostasis. North Carolina: Duke University Medical Center, 2005; p. 24-35.

12. Sukma DER. Pengaruh ekstrak daun pepaya (Carica papaya L.) terhadap waktu perdarahan tikus wistar (Rattus Nurvegicus). Banda Aceh: Fakultas Kedokteran Gigi Universitas Syiah Kuala; 2015; p. 40-60.

13. Wuisan J, Hutagalung B, Lino W. Pengaruh Pemberian Ekstrak Biji Pinang (Areca Catechu L.) Terhadap Waktu Pendarahan Pasca Ekstraksi Gigi Pada Tikus Jantan Wistar (Rattus Norvegicus L.). Jurnal Ilmiah Sains. 2015;15(2):129-34.

14. Nazarizadeh A, Mikaili P, Moloudizargari M, 
Kainde, Pangemanan, Hutagalung: Uji efektivitas daun sendok ...

Aghajanshakeri S,Javaherypour S. Therapeutic uses and pharmacological properties of Plantago major L. and its active constituents. J Basic Appl Sci Res. 2013;3(9):212-8.

15. Zubair M. Genetic and environmental effects on polyphenols in Plantago major. ISSN 16543580. Balsgard: Swedish University of
Agricultural Sciences, 2010; p.3-30.

16. Audini D. Pengaruh ekstrak bunga pepaya jantan (Carica papaya L.) terhadap waktu perdarahan (Bleeding Time) pada tikus Wistar [Skripsi]. Manado: Fakultas Kedokteran Universitas Sam Ratulangi.Manado; 2016. 